\title{
PENGEMBANGAN LEMBAR KERJA SISWA (LKS) DENGAN MODEL PROBLEM BASED LEARNING (PBL) DIPADU THINK PAIR SHARE (TPS)
}

\author{
Frans Tunggu Palura1, Diyah Ayu Widyaningrum² \\ ${ }^{1}$ Mahasiswa Pendidikan Biologi, FPIEK, IKIP Budi Utomo malang \\ ${ }^{2}$ Dosen Pendidikan Biologi, FPIEK, IKIP Budi Utomo malang \\ e-mail: Franskilimandang@gmail.com
}

\begin{abstract}
This study aims to produce LKS based on problem based learning coupled think pair share and can be applied in teaching and learning process, describe the implementation of learning, the level of legibility of students after using LKS based prbolem based learning combined think pair share. This research is a development research using 4-D development model that is Define (Define), Design (Design), Develop (Development), while Disseminate stage (Dissemination) is not done due to time constraint. The pilot phase was conducted at SMA Negeri 1 Kambera in class XI-IPA which amounted to 8 students. The results showed that in accordance with the study of LKS, the worksheet of students based on problem based learning combined think pair share process that has been developed declared eligible for trial. Implementation of learning using LKS has reached / obtained the average implementation of\% The level of legality of LKS based on problem based learning combined think pair share of students obtain the overall average of $3.87 \%$ stated in the category Very Worthy, it shows that most Students argue the material and media used are easy to understand and the appearance of student worksheets (LKS) interesting.
\end{abstract}

Keywords: Student Worksheet, Problem Based Learning, Think Pair Share

\section{PENDAHULUAN}

Pendidikan yang terjadi selama ini masih menjadi permasalahan yang langsung dihadapi oleh guru dalam pemberian layanan kepada peserta didik yang beragam gaya belajarnya. Perbedaan gaya belajar yang tidak dapat dilayani dengan merata akan menjadikan adanya perbedaan motivasi dan hasil belajar karena gaya belajar merupakan suatu kunci untuk proses penerimaan informasi yang akan diberikan kepada siswa. Salah satu cara untuk memfasilitasi gaya belajar siswa yang beragam dengan penggunaan bahan ajar dalam kegiatan belajar mengajar.

Bahan ajar diperlukan untuk dapat mencapai keberhasilan dalam belajar, sehingga siswa dapat aktif dalam belajar serta mudah dalam menerima pelajaran.
Bahan ajar merupakan segala bentuk bahan yang digunakan untuk membantu guru atau instruktur dalam melaksanakan proses pembelajaran di kelas (Majid, 2012).

Berdasarkan hasil observasi di SMA Negeri 1 Kambera khususnya pada kelas XI IPA, peneliti menemukan fakta bahwa guru mata pelajaran biologi belum pernah menggunakan lembar kegiatan siswa (LKS) dalam kegiatan belajar mengajar. Cara guru dalam penyampaian materi masih dalam bentuk ceramah dan mengisi buku PR yang berisi ringkasan materi dan latihan soal, sehingga buku tersebut belum bisa mengarahkan siswa pada kegiatan belajar yang terarah. Siswa berbicara dengan teman sebangku saat proses belajar mengajar berlangsung. 
Peneliti menawarkan kepada guru mata pelajaran biologi agar menggunakan LKS pada saat proses belajar mengajar. LKS tersebut berbasis model pembelajaran Problem Based Learning (PBL) dipadu Think Pair Share (TPS) yang dapat mengarahkan siswa untuk belajar lebih baik. Penggabungan dua model pembelajaran antara PBL dengan TPS dimaksudkan untuk bisa meningkatkan kemampuan berpikir kritis dan hasil belajar mahasiswa. Karena pada model pembelajaran PBL dan TPS mempunyai karakteristik yang sama yaitu meningkatkan kemampuan berpikir dan tahap berbagi untuk menyajikan hasil diskusi/ Sharing (Riskiwati, 2015).

Pembelajaran dengan model PBL dipadu TPS mengarahkan siswa belajar dengan cara memberi permasalahan pada siswa dalam bentuk cerita dan meminta siswa menyelesaikan permasalahan dengan cara berpasangan sehingga siswa memiliki kesempatan untuk bertukar pikiran dengan teman sebaya (pasangannya). Siswa akan terdorong untuk menganalisis dan mengevaluasi suatu informasi sehingga mereka dapat saling mendiskusikan masalah-masalah tersebut dengan pasangannya untuk menemukan solusi dari masalah tersebut. Lembar Kerja Siswa (LKS) berisi materi pokok sistem pernapasan.

Berdasarkan uraian di atas maka mendorong peneliti untuk melakukan Pengembangan lembar kerja siswa (LKS) dengan judul "Pengembangan Lembar Kerja Siswa dengan Model Pembelajaran Problem Based Learning dipadu Think Pair Share pada Materi Sistem Pernapasan di Kelas XI SMA Negeri 1 Kambera".

\section{METODE PENELITIAN}

Model penelitian dan pengembangan ini mengikuti model Thiagarajan (1974), meliputi define,design, develop, dan disseminate tetapi penelitian ini hanya sampai tahap develop. Instrumen yang digunakan dalam penelitian ini adalah lembar validasi kelayakan materi, kelayakan media, praktisi lapangan dan angket uji keterbacaan siswa. Pengumpulan data dilakukan dengan teknik validasi yang meliputi validasi materi, media, praktisi lapangan, dan pengisisan angket uji keterbacaan pada kelas yang telah menempuh sistem pernapasan yaitu kelas XI.

Data yang diperoleh merupakan hasil dari berbagai validasi kemudian diolah/ dianalisis dengan skala likert dengan kriteria skor 1 = Tidak Baik, 2 = Kurang Baik, 3 = Baik, 4 = Baik Sekali (Akbar, 2013). Presentase kelayakan LKS kemudian dihitung dengan rumus sebagai berikut:

$$
\text { Kelayakan LKS }=\frac{\text { Jumlah skor diperoleh }}{\text { Jumlah skor total }} \times 100 \%
$$

Perhitungan hasil persentase dari analisis lembar validasi diinterpretasikan ke dalam kriteria pada Tabel 1 berikut.

Tabel 1. Kriteria Persentase dari Analisis Lembar Validasi

\begin{tabular}{ccc}
\hline Skor & Persentase & Kriteria \\
\hline 1 & $0 \%-20 \%$ & Tidak Layak \\
\hline 2 & $21 \%-40 \%$ & Kurang Layak \\
\hline 3 & $41 \%-60 \%$ & Cukup Layak \\
\hline 4 & $61 \%-80 \%$ & Layak \\
\hline 5 & $81 \%-100 \%$ & Sangat Layak \\
\hline & & Sumber (Akbar, 2013)
\end{tabular}


Perhitungan hasil kriteria penilaian kriteria pada Tabel 2 berikut. uji keterbacaan diinterpretasikan ke dalam

Tabel 2 Kriteria Penilaian Uji Keterbacaan Siswa

\begin{tabular}{ccc}
\hline Skor & Persentase & Kriteria \\
\hline 1 & $3,26-4,00$ & Sangat Layak \\
\hline 2 & $2,52-3,25$ & Layak \\
\hline 3 & $1,26-2,50$ & Kurang Layak \\
\hline 4 & $1,01-1,75$ & Tidak Layak \\
\hline \multicolumn{3}{c}{ Sumber (Suyanto dan Sartinem, 2009) }
\end{tabular}

\section{HASIL DAN PEMBAHASAN}

Berdasarkan penelitian mengenai pengembangan lembar kerja siswa LKS dengan model pembelajaran Problem Based Learning dipadu Think Pair Share materi sistem respirasi pada manusia yang telah dilakukan, maka diperoleh hasil penelitian serta pembahasannya pada masing-masing tahap Pendefinisian (Define), perancangan (Design), dan pengembangan (Develop) adalah sebagai berikut:

\section{Tahap Pendefinisian (Define)}

a. Analisis awal-akhir yang meliputi analisis SK, KD, Indikator. Standar Kompetensi (SK), yaitu menjelaskan struktur dan fungsi organ manusia dan hewan tertentu, kelainan/ penya-kit yang mungkin terjadi serta implikasinya. Kompetensi Dasar (KD), yaitu menjelaskan keterkaitan antara struktur, fungsi, dan proses serta kelainan/ penyakit yang dapat terjadi pada sistem pernapasan pada manusia dan hewan (misalnya burung).

b. Analisis Konsep

Pada langkah ini peneliti melakukan analisis pada konsep-konsep yang akan diajarkan pada proses pembela-jaran. Analisis ini bertujuan untuk mengidentifikasi, merinci dan menyusun secara sistematis konsep-konsep relevan yang akan diajarkan. Berdasarkan kurikulum KTSP untuk kelas XI, Materi Sistem respirasi pada ma- nusia yaitu organ pernapasan pada manusia, mekanisme pernapasan pada manusia, udara pernapasan dan pertukaran gas dalam pernapasan, kelainan atau gangguan pada sistem pernapasan, sistem pernapasan pada burung.

c. Analisis Tugas

Kegiatan ini ditujukan untuk mengidentifikasi ketrampilan ketrampilan yang dimiliki oleh siswa yang akan dikembangkan dalam pembelajaran.

d. Analisis Perumusan Tujuan Pembelajaran.

Pada tahap ini peneliti melakukan perumusan hasil analisis tugas dan analisis konsep diatas menjadi tujuan pencapaian hasil belajar.

2. Perancangan (Design)

Pada tahap perancangan dilakukan pembuatan prototype LKS berbasis model PBL dipadu TPS. LKS berisi tugas sesuai langkah-langkah pada PBL dipadu TPS.

3. Pengembangan (Develop)

Tahap pengembangan yaitu tahap dimana beberapa validator akan memberikan penilaian dan pemberian saran perbaikan terhadap LKS yang telah disusun oleh para peneliti. Validasi dilakukan oleh dua orang dosen biologi dan praktisi lapangan selanjutnya dilakukan uji keterbacaan siswa. Hasil validasi dan uji keterbacaan ditunjukkan pada Tabel 3 sampai 8. 
Tabel 3. Data Validator Ahli Materi Secara Umum

\begin{tabular}{lcc}
\hline Aspek & \% Tiap Kriteria & Kategori \\
\hline Cakupan & 75 & Layak \\
\hline Pengulangan & 75 & Layak \\
\hline Kebenaran konsep & 50 & Cukup Layak \\
\hline Aplikasi & 150 & Cukup Layak \\
\hline Susunan materi & 75 & Layak \\
\hline Hubungan antar materi & 50 & Cukup Layak \\
\hline Penyajian materi & 75 & Layak \\
\hline
\end{tabular}

Tabel 4. Data Validator Konsep Materi

\begin{tabular}{lcc}
\hline \multicolumn{1}{c}{ Aspek } & \% Tiap Kriteria & Kategori \\
\hline Definisi & 50 & Cukup Layak \\
\hline Organ pernapasan & 50 & Cukup Layak \\
\hline Fungsi & 100 & Sangat Layak \\
\hline Inspirasi dan ekspirasi & 100 & Sangat Layak \\
\hline Pernapasan dada dan perut & 75 & Layak \\
\hline Volume udara pernapasan & 50 & Cukup Layak \\
\hline Mekanisme pernapasan & 75 & Layak \\
\hline Asfiksi & 75 & Layak \\
\hline Sesak napas & 75 & Layak \\
\hline Solusi gangguan pernapasan & 75 & Layak \\
\hline Definisi pernaapasan burung & 75 & Layak \\
\hline Organ pernapasan burung & 50 & Cukup Layak \\
\hline Fungsi pundi-pundi udara & 75 & Layak \\
\hline Beda inspirasi dan ekspirasi & 75 & Layak \\
\hline
\end{tabular}

Tabel 5. Data Validator Media LKS Secara Umum

\begin{tabular}{lcc}
\hline \multicolumn{1}{c}{ Aspek } & \% Tiap Kriteria & Kategori \\
\hline Jenis huruf & 75 & Layak \\
\hline Ukuran huruf & 75 & Layak \\
\hline Jarak & 75 & Layak \\
\hline Warna & 75 & Layak \\
\hline Tampilan gambar & 50 & Cukup Layak \\
\hline Penempatan gambar & 75 & Layak \\
\hline Pembagian materi & 75 & Layak \\
\hline Penomoran & 50 & Cukup Layak \\
\hline Tata letak & 75 & Layak \\
\hline Urutan & 75 & Layak \\
\hline Keterbacaan & 100 & Sangat Layak \\
\hline Kemudahan penggunaan & 100 & Sangat Layak \\
\hline Petunjuk Penggunaan & 75 & Layak \\
\hline
\end{tabular}

Tabel 6. Data Validator LKS Secara Umum oleh Guru Biologi.

\begin{tabular}{lcc}
\hline \multicolumn{1}{c}{ Aspek } & \% Tiap Kriteria & Kategori \\
\hline Cakupan materi & 75 & Layak \\
\hline Penggulangan & 100 & Sangat Layak \\
\hline Kebenaran konsep & 75 & Layak \\
\hline Aplikasi & 100 & Sangat Layak \\
\hline Susunan materi & 75 & Layak \\
\hline Hubungan antar materi & 100 & Sangat Layak \\
\hline Sistematika materi & 100 & Sangat Layak \\
\hline Jenis huruf & 100 & Sangat Layak \\
\hline Ukuran huruf & 100 & Sangat Layak \\
\hline
\end{tabular}




\begin{tabular}{lcc}
\hline \multicolumn{1}{c}{ Aspek } & \% Tiap Kriteria & Kategori \\
\hline Jarak & 75 & Layak \\
\hline Background & 75 & Layak \\
\hline Tampilan gambar & 75 & Layak \\
\hline Penempatan gambar & 100 & Sangat Layak \\
\hline Pembagian materi & 75 & Layak \\
\hline Penomoran & 100 & Sangat Layak \\
\hline Tata letak & 75 & Layak \\
\hline Tata letak urutan LKS & 100 & Sangat Layak \\
\hline Keterbacaan & 75 & Layak \\
\hline Kemudahan & 75 & Layak \\
\hline Petunjuk & 100 & Sangat Layak \\
\hline
\end{tabular}

Tabel 7. Data Saran Perbaikan LKS oleh Ahli Materi, Media dan Praktisi Lapangan.

\begin{tabular}{|c|c|c|}
\hline $\begin{array}{c}\text { Penilai } \\
\text { Validasi Ahli }\end{array}$ & Sebelum Revisi & Sesudah Revisi \\
\hline Ahli Materi & $\begin{array}{l}\text { Sebelum direvisi langkah kerja } \\
\text { dalam LKS belum disertyakan } \\
\text { dengan sintaks PBL dipadu TPS } \\
\text { dan lembar jawaban siswa } \\
\text { belum diisi dengan jawaban } \\
\text { siswa. }\end{array}$ & $\begin{array}{l}\text { Sesudah direvisi langkah kerja } \\
\text { dalam LKS sudah disertyakan } \\
\text { dengan sintaks PBL dipadu TPS } \\
\text { dan lembar jawaban siswa sudah } \\
\text { diisi dengan jawaban siswa. }\end{array}$ \\
\hline Ahli Media & $\begin{array}{l}\text { Sebelum direvisi gambar dan } \\
\text { hal yang ditunjukkan pada } \\
\text { gambar belum disertakan dan } \\
\text { tahun pembuatan LKS belum } \\
\text { disertakan. }\end{array}$ & $\begin{array}{l}\text { Sesudah direvisi gambar dan hal } \\
\text { yang ditunjukkan pada gambar } \\
\text { sudah disertakan dan tahun } \\
\text { pembuatan LKS } \\
\text { disertakan. }\end{array}$ \\
\hline Guru/ Praktisi & $\begin{array}{l}\text { Sebelem melakukan uji } \\
\text { keterbacaan terhadap siswa, ada } \\
\text { hal-hal yang perlu diperbaiki } \\
\text { yaitu penggunaan jarak (dan } \\
\text { alinea). }\end{array}$ & $\begin{array}{l}\text { Sesudah diperbaiki penggunaan } \\
\text { jarak (dan alinea). kemudia } \\
\text { melakukan uji keterbacaan } \\
\text { terhadap siswa. }\end{array}$ \\
\hline
\end{tabular}

Tabel 8. Data Uji Keterbacaan Siswa Terhadap LKS yang Dikembangkan.

\begin{tabular}{clccccccccc}
\hline No & \multicolumn{1}{c}{ Nama siswa } & \multicolumn{6}{c}{ Aspek penilaian } & \multicolumn{3}{c}{ Skor } \\
\hline & & $\mathbf{1}$ & $\mathbf{2}$ & $\mathbf{3}$ & $\mathbf{4}$ & $\mathbf{5}$ & $\mathbf{6}$ & $\mathbf{7}$ & $\mathbf{8}$ & \\
\hline 1 & Cindi Putri Amelia & 4 & 4 & 4 & 3 & 4 & 4 & 4 & 4 & 31 \\
\hline 2 & Anastasia T. Hamu & 4 & 4 & 4 & 4 & 4 & 4 & 3 & 4 & 31 \\
\hline 3 & Maya K. Ngguna & 4 & 4 & 4 & 4 & 3 & 4 & 4 & 4 & 31 \\
\hline 4 & Donisius W. Wohangara & 4 & 4 & 4 & 3 & 4 & 4 & 4 & 4 & 31 \\
\hline 5 & Novita T. Nalu & 4 & 4 & 4 & 3 & 4 & 4 & 4 & 4 & 31 \\
\hline 6 & Olen K. Nggiku & 4 & 4 & 4 & 4 & 4 & 3 & 4 & 4 & 31 \\
\hline 7 & Aditya Ng. Nday & 4 & 4 & 4 & 4 & 3 & 4 & 4 & 4 & 31 \\
\hline 8 & Novryeni Habi R. & 4 & 4 & 4 & 4 & 4 & 4 & 3 & 4 & 31 \\
\hline
\end{tabular}

Kedelapan aspek penilaian uji keter- dasi ahli materi secara umum, konsep materi, bacaan oleh siswa meliputi desain cover, media secara umum, validasi oleh guru/ gambar, font, bahasa, pemahaman materi, praktisi dan analisis data hasil keterbacaan soal, kemudahan materi untuk diingat, lembar kerja siswa (LKS) tahap terhadap petunjuk dan kegiatan LKS.

\section{Analisis Data} siswa. Analisis data hasil validasi terdiri dari analisis lembar validasi sebagai berikut.

Analisis data dalam penelitian terdiri dari 5 macam, yaitu analisis data hasil vali- 
Tabel 9. Analisis Hasil Validasi Ahli Materi, Media dan Praktisi Lapangan.

\begin{tabular}{ccc}
\hline Validator & Nilai & Kriteria \\
\hline Materi & $67,85 \%$ & Layak \\
\hline Media & $75,00 \%$ & Layak \\
\hline Praktisi Lapangan & $87,50 \%$ & Sangat Layak \\
\hline
\end{tabular}

Berdasarkan hasil validasi kelayakan materi, media dan praktisi lapangan setiap aspek maka dapat diketahui rata-rata kelayakan materi sebesar $67,85 \%$ dengan kriteria layak, kelayakan media mempero-leh hasil sebesar
75\% dengan kriteria layak, kelayakan LKS secara umum oleh guru praktisi lapangan memperoleh nilai sebesar $87,5 \%$ dengan kategori sangat layak.

Tabel 10. Analisis Hasil Uji Keterbacaan Siswa.

\begin{tabular}{ccc}
\hline Keterbacaan & Nilai & Kriteria \\
\hline Materi dan media LKS & $3,87 \%$ & Sangat Layak \\
\hline
\end{tabular}

Berdasarkan hasil penilaian keterbacaan oleh siswa terhadap LKS diperoleh hasil penilaian sebesar 3,87\% dengan kategori sangat layak.

\section{Kajian Produk yang Telah Direvisi}

Produk LKS hasil pengembangan merupakan salah satu bahan ajar yang digunakan untuk memfasilitasi kegiatan pembelajaran dalam penerapan model PBL dipadu TPS. Depdiknas (2008) mengemukakan bahwa bahan ajar digunakan untuk membantu guru dalam melaksanakan kegiatan pembelajaran. Bahan ajar yang digunakan dalam penelitian ini adalah LKS. LKS adalah lembaran-lembaran berisi tugas yang harus dikerjakan oleh siswa. Lembar kerja ini berisi petunjuk dan langkah-langkah untuk menyelesaikan suatu tugas yang diberikan oleh guru kepada siswanya. Tugas-tugas yang diberikan kepada siswa dapat berupa tugas teori dan atau tugas praktik Widyantini (2013). LKS berisi halaman judul, halaman sampul, kata pengantar, daftar isi, latar belakang, sintaks model pembelajaran PBL dipadu TPS yang tercermin dalam kegiatan pembelajaran (orientasi siswa terhadap masalah, mengorganisasikan siswa untuk belajar, mengembangkan dan menyajikan hasil karya, menganalisis dan mengevaluasi proses pemecahan masalah) (Rizkiwati dan Jailani, 2005).

Kelebihan model pembelajaran PBL dipadu TPS adalah karakteristik kedua model yang sama yaitu berpikir dan berbagi atau menyajikan hasil diskusi. Oleh karena itu dalam penelitian ini peneliti menggabungkan model pembelajaran PBL dengan TPS sehingga terbentuk sebuah model pembelajaran yang mampu meningkatkan kemampuan berpikir siswa. LKS sistem pernapasan terdiri dari 5 bagian, seluruhnya menggunakan tampilan warna yang sama yaitu hijau. Warna hijau melambangkan kestabilan, semangat, keseimbangan, harmoni, alam, dan lingkungan (Nugroho, 2008).

\section{SIMPULAN DAN SARAN}

a. Bagi guru yang ingin menerapkan LKS, sebaiknya meminta siswa mempelajari petunjuk penggunaan LKS supaya dapat membantu siswa dalam mengerjakan tugas-tugas yang diperlukan. 
b. Menyampaikan LKS hasil pengembangan pada forum diskusi Musyawarah Guru Mata pelajaran (MGMP).

c. Memuat LKS hasil pengembangan pada fasilitas e-book dari dinas pendidikan maupun lembaga sekolah.

d. Melakukan uji pengembangan lebih lanjut pada tahapan develop dan disseminate.

\section{RUJUKAN}

Akbar. (2013). Pengembangan Lembar Kerja Siswa (LKS) Berbasis Pendekatan Saintifik pada Pembelajaran Akuntansi di SMK Negeri 1 Surakarta. Jurnal "Tata Arta" UNS. 7.

Baiq Yuliana Rizkiwati1) Huzain Jailani2). (2015). Efektivitas Model Pembelajaran Problem Based Learning Dipadu Think Pair Share terhadap Kemampuan Berpikir Kritis dan Hasil Belajar Mahasiswa. Jurnal EducatiO, 7.

Majid (2012). Pengembangan Lembar Kegiatan Siswa Materi Luas Bangun Datar Berbasis Metode Pembelajaran Discovery untuk Siswa Sekolah Menengah Pertama. Jurnal Pendidikan
Matematika FKIP Univ. Muhammadiyah Metro, 4.

Nugroho. (2008). Warna Hijau Melambangkan Kestabilan, Semangat, Keseimbangan, Harmoni, Alam, dan Lingkungan. Jurnal Educatio, 8.

Rizkiwati, Baiq Yuliana dan Jailani, Yuliana. 2015. Efektivitas Model Pembelajaran Problem Based Learning Dipadu Think Pair Share Terhadap Kemampuan Berpikir Kritis dan Hasil Belajar Mahasiswa. Jurnal Education. Vol. 10 (2), (Online) download.portalgaruda. org/article.php?...EFEKTIVITAS\%20

MODEL\%20PEMBELA..., diakses 7 Desember 2017.

Suyanto dan Sartinem. (2009). Pengembangan Lks Berbasis Inkuiri Terbimbing untuk Pembelajaran Fluida Statis di SMAN 1 Kotaagung. Jurnal LKS berbasis inkuiri terbimbing, pembelajaran fluida statis, pengembangan LKS, 5.

Widyantini. (2013). Pengembangan Lembar Kegiatan Siswa Materi Luas Bangun Datar Berbasis Metode Pembelajaran Discovery untuk Siswa Sekolah Menengah Pertama. Jurnal Pendidikan Matematika FKIP Univ. Muhammadiyah Metro, 4. 